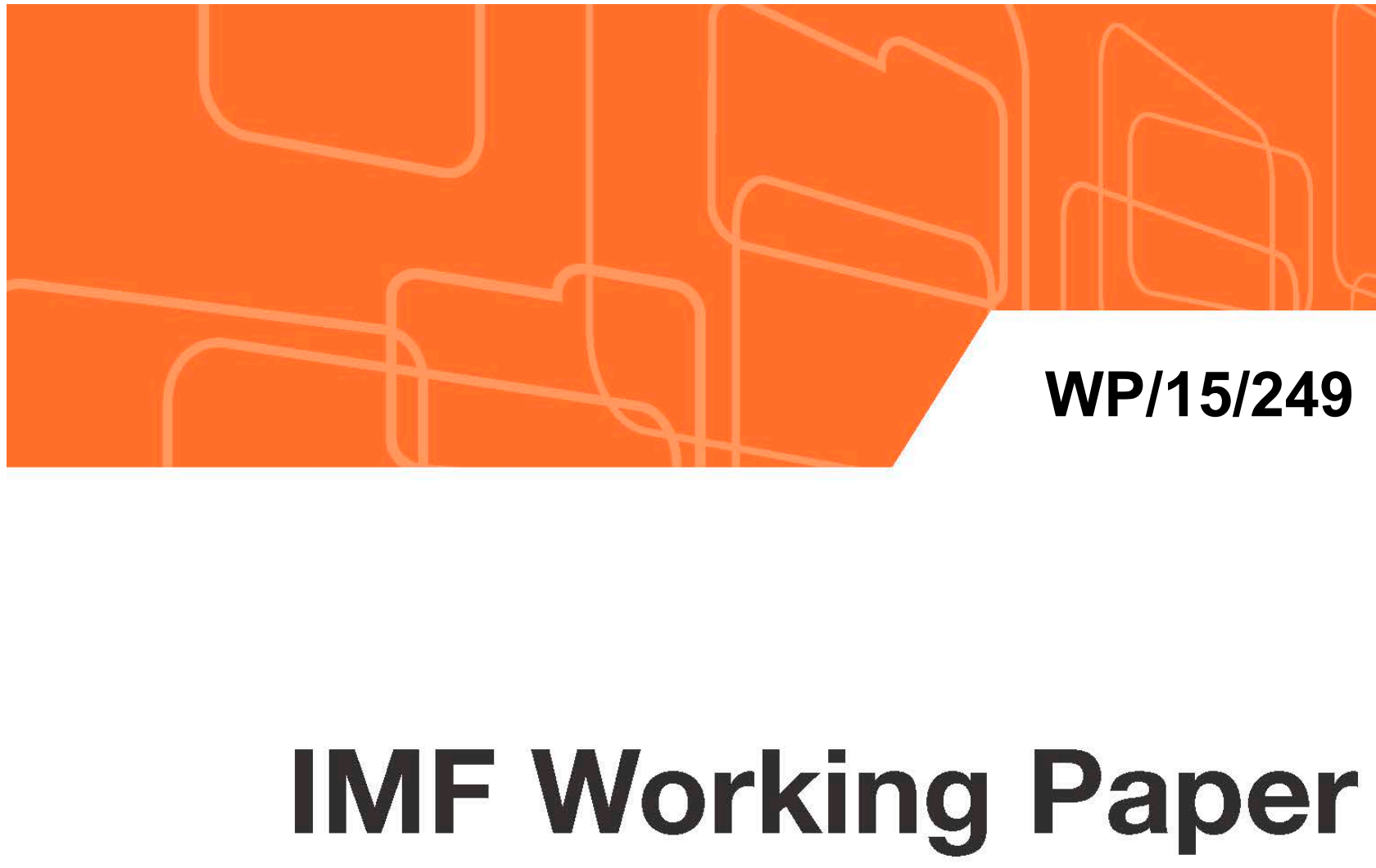

\title{
Bank Profitability and Risk-Taking
}

by Natalya Martynova, Lev Ratnovski, and Razvan Vlahu

IMF Working Papers describe research in progress by the author(s) and are published to elicit comments and to encourage debate. The views expressed in IMF Working Papers are those of the author(s) and do not necessarily represent the views of the IMF, its Executive Board, or IMF management. 


\title{
IMF Working Paper
}

Research Department

\section{Bank Profitability and Risk-Taking}

Prepared by Natalya Martynova, Lev Ratnovski, and Razvan Vlahu'

Authorized for distribution by Giovanni Dell'Ariccia

November 2015

\section{IMF Working Papers describe research in progress by the author(s) and are published to elicit comments and to encourage debate. The views expressed in IMF Working Papers are those of the author(s) and do not necessarily represent the views of the IMF, its Executive Board, or IMF management.}

\begin{abstract}
Traditional theory suggests that more profitable banks should have lower risk-taking incentives. Then why did many profitable banks choose to invest in untested financial instruments before the crisis, realizing significant losses? We attempt to reconcile theory and evidence. In our setup, banks are endowed with a fixed core business. They take risk by levering up to engage in risky 'side activities'(such as market-based investments) alongside the core business. A more profitable core business allows a bank to borrow more and take side risks on a larger scale, offsetting lower incentives to take risk of given size. Consequently, more profitable banks may have higher risk-taking incentives. The framework is consistent with cross-sectional patterns of bank risk-taking in the run up to the recent financial crisis.

JEL Classification Numbers: G21, G24, G28.

Keywords: Banks; Risk-Taking; Bank Capital; Repo Markets; Crises. Authors’ E-Mail Address: 1ratnovski@imf.org

\footnotetext{
${ }^{1}$ Martynova and Vlahu are with the De Nederlandsche Bank. The views in this paper do not necessarily represent the views of the DNB. We thank Toni Ahnert, Mike Burkart, Santiago Carbo-Valverde, Stijn Claessens, Giovanni Dell'Ariccia, Tryggvi Gudmundsson, Luc Laeven, David Martinez-Miera, Mark Mink, Lars Norden, Bruno Parigi, Enrico Perotti, Rafael Repullo, Jean-Charles Rochet, Rajdeep Sengupta, Javier Suarez, Alexander Tieman, Wolf Wagner, Tanju Yorulmazer, as well as seminar and conference participants at IMF, DNB, University of Amsterdam, IBEFA 2014 Denver, FMA 2014 Nashville, IFABS 2014 Lisbon, SUERF and Finlawmetrics 2014 at Bocconi, EEA 2014 Toulouse, MFA 2015 Chicago, ERMAS 2015 conference, Banco Central do Brazil and Banco Central del Uruguay for helpful comments.
} 


\section{Table of Contents}

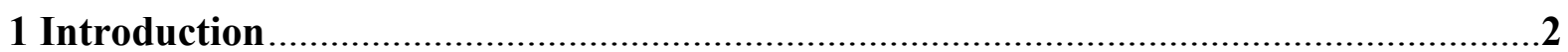

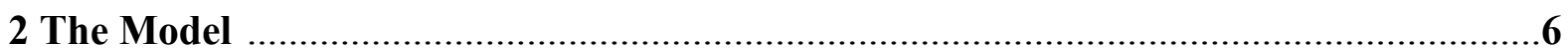

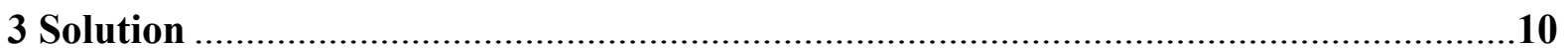

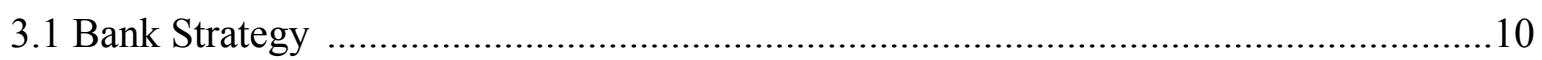

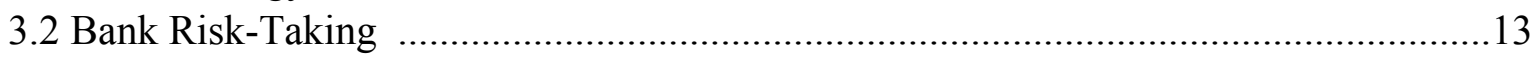

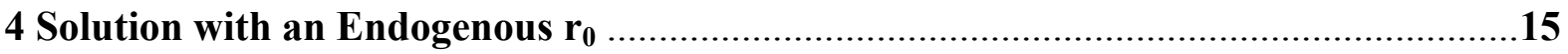

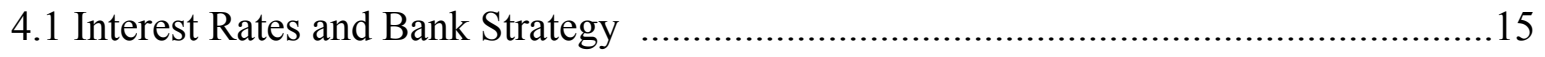

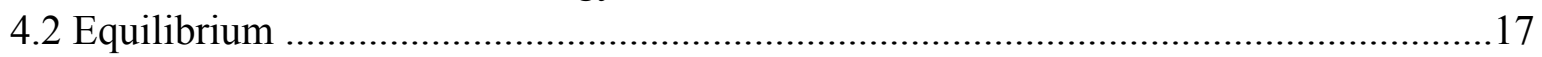

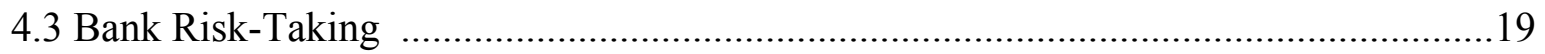

5 Extensions

5.1 Effort in the Core Project ........................................................................................21

5.2 Monetary Policy and Bank Risk-Taking ..............................................................23

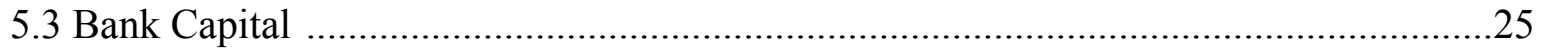

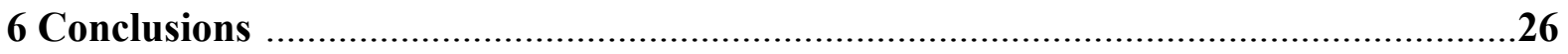

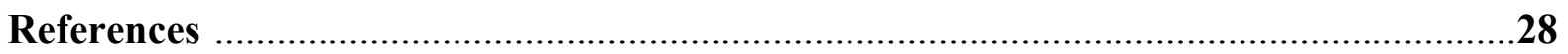

Proofs 


\section{Introduction}

The recent crisis revealed a surprising amount of opportunistic risk-taking in otherwise very profitable financial institutions. For example, UBS in Switzerland had a unique wealth management franchise, with a stable return on allocated capital in excess of $30 \%$ prior to the crisis (UBS, 2007). It rapidly, over just two years, accumulated a large portfolio of credit default swaps (CDS), lost over $\$ 50$ billion in 2008, and had to be rescued. Washington Mutual, once called "The Walmart of Banking", had profitable consumer and small business operations. It became prior to the crisis one of the most aggressive mortgage lenders, lost $\$ 22$ billion on subprime exposures, and was liquidated. The insurance company AIG was one of only three AAA-rated companies in the U.S. It started selling CDS protection on senior tranches of asset backed securities in 2005 and lost over $\$ 100$ billion - 10\% of assets - in 2008 (AIG, 2008), wiping out shareholder equity and inducing a bailout. Similar investments-related disasters occurred in many other well-established financial institutions in the U.S. and Europe.

Significant risk-taking in profitable institutions seems to contradict the traditional predictions of corporate finance models. Shareholders are protected by limited liability and have incentives to take risk to maximize their option-like payoff (Jensen and Meckling, 1976). But the risk-taking incentives should be lower in more profitable firms, as they stand to lose more shareholder value if downside risks realize (Keeley, 1990). Therefore it is puzzling why some of the world's most profitable financial institutions chose to become exposed to risky and untested market-based instruments on such a large scale.

This paper attempts to reconcile theory and evidence. Our key observation is that in Jensen and Meckling-type models, firms choose the risk of a portfolio of a given size. Yet bank risk-taking in the run-up to the crisis took a different form. Think of banks as being organized around a core business

that generates stable, long-term returns (e.g., wealth management for UBS, retail relationships for Washington Mutual). In the run-up to the crisis, banks levered up - expanded the balance sheet - to engage in risky 'side activities' (often market-based investments) alongside the stable core 
business. ${ }^{1}$ We show that when banks take such additional risk rather than manipulate their core portfolio, the traditional result that higher profitability reduces bank risk-taking incentives does not always hold. The reason is that, in the presence of a leverage constraint, a more profitable core business allows the bank to borrow more and engage in risky side activities on a larger scale. Larger scale of risk-taking can offset lower incentives to take risk of given size. As a result, banks with a more profitable core business may have higher - not lower - incentives to take risk. Put differently, when banks take risk through side activities, a profitable core business enables leverage and hence risk-taking. With an exceeding scale of side activities, even very profitable banks may choose to take risk. ${ }^{2}$

The model's comparative statics fit well with the stylized patterns of bank risk-taking in the runup to the crisis. We show that profitable banks are more likely to take risk when leverage constraints are less binding, other else equal. This may stem from a better institutional environment with more protection of creditor rights, and thus explain why most banks affected by the crisis were in advanced economies. Profitable banks are also more likely to take risk when the funding for their side activities (market-based investments) is senior to the funding for their core business. This highlights the role of senior repo funding in contributing to pre-crisis vulnerabilities (Gorton and Metrick, 2012; Acharya and Öncü, 2013).

The model offers itself to a number of extensions. In one extension, we allow the bank to invest in effort to increase the quality (or, equivalently, reduce the risk) of its core business. We find that a bank may strategically combine effort to increase the quality of the core business with opportunistic side activities. The reason is that a better core business allows the bank to lever up more and take risk on a larger scale. The literature has often associated this seeming inconsistency with a "clash of cultures" between conservative bankers and risk-loving traders (Froot and Stein,

\footnotetext{
${ }^{1}$ The risky investments included accumulating senior tranches of asset-backed securities (Gorton, 2010), selling protection on senior tranches of asset backed securities through CDS contracts (Acharya and Richardson, 2009), undiversified exposures to housing (Shin, 2009), etc.

${ }^{2}$ An interesting illustration is that prior to the crisis UBS ran the largest trading floor by physical size in the world (103,000 sq.ft., the size of two football fields). Our argument is that a bank with a weaker core business might have been unable to support such a massive non-core operation. Indeed, as of 2014, the UBS trading floor is "almost empty" ("Empty Floors Fray Traders' Nerves," Wall Street Journal, July 14, 2014).
} 
1998). We explain it based purely on shareholder value maximization.

In another extension, we consider the effects of monetary policy on bank risk-taking, distinguishing between risk-taking in the core business versus that in side activities. Lax monetary policy reduces the bank's cost of funding, increasing its profitability. Within the core business, higher profitability implies lower incentives to take risk because it makes a bank's limited liability less binding, so the shareholders internalize more of the downside risk realization. In contrast, for side activities, higher profitability implies that the bank can borrow more and take risk on a larger scale. As a result, lax monetary policy may induce bank risk-taking in market-based side activities. The finding of a differential effect of monetary policy on bank risk-taking in the core business versus that in side activities contributes to the debate on the impact of monetary policy on bank risk-taking (see e.g., Dell'Ariccia et al., 2013, 2014; and Jiménez et al., 2014). It suggests, for example, that accommodative monetary policy may induce risk-taking relatively less in small banks involved in relationship lending, but relatively more in large banks active in financial markets.

The paper relates to the literature on the link between bank profitability and risk-taking. (Profitability is a static concept, its dynamic counterparts are bank franchise value or charter value.) The accepted first-order effect is that higher profitability reduces bank risk-taking incentives (Keeley, 1990; Demsetz et al., 1996; Repullo, 2004; among others). But some papers caution that the relationship might be more complex. First, banks may take risk in order to generate profits (e.g., to satisfy higher bank capital requirements, see Blum, 1999; Hellmann et al., 2000; Matutes and Vives, 2000). Second, profitability allows banks to build up capital, which makes capital requirements less binding, so that banks are less averse to occasional losses (Calem and Rob, 1999; Perotti et al., 2011). Our model proposes a novel effect, closely linked to the pre-crisis experience, where a profitable core business enables banks to borrow more and take larger-scale risks in side activities.

The literature on the effects of bank capital on bank risk-taking during the 2008 crisis provides interesting empirical background for our analysis. (Bank capital is similar to bank profitability as both capture the exposure of bank shareholders to downside risk realizations, and affect a bank's 
capacity to take on additional leverage. We establish the equivalence between bank capital and bank profitability in our model in Section 5.3.) In Beltratti and Stulz (2012), higher pre-crisis capital improves bank performance during the 2008 crisis, but only in a sample with banks from both advanced and emerging economies and not in all specifications. In Berger and Bouwman (2013), higher capital improves U.S. banks' performance during multiple banking crises, but not specifically during the 2008 crisis. In contrast, studies that focus exclusively on banks in advanced economies during the 2008 crisis suggest a weak or indeed negative link between pre-crisis bank capital and performance. Huang and Ratnovski (2009) on a sample of large OECD banks find no relationship between pre-crisis bank capital and performance during the crisis. Any positive impact of bank capital on performance is driven by banks with extremely low capital, and any equity above $4 \%$ of assets did not improve bank stability. Camara et al. (2013) show that better-capitalized European banks took more risk before the 2008 crisis. IMF's Global Financial Stability Report (2009) on a sample of 36 major global banks finds that banks that were intervened in during the crisis had statistically higher capital metrics (risk-weighted or not) before the crisis than banks that did not require an intervention. The latter effects, which suggest that ex ante capital was positively associated with bank risk-taking, are consistent with the message of our paper. ${ }^{3}$

Our paper also relates to the literature on the link between institutional environment and bank risk-taking. The international economics literature documents that better institutional environment may enable countries to accumulate more liabilities (Mendoza et al., 2009), often leading to more severe crises (Giannonne et al., 2011; Gourinchas et al., 2011; Gennaioli et al., 2014). Similarly, in our model, banks in countries with better protection of creditor rights can lever up more easily, facilitating risk-taking. In the banking literature, the link between institutional environment, creditor rights and bank risks was examined by Laeven (2001), La Porta et al. (2003), and Boyd and Hakenes (2014).

More generally, there are parallels between our analysis and those of Myers and Rajan (1998)

\footnotetext{
${ }^{3}$ Also, on pre-crisis data, Barth et al. (2006) find no relationship between bank capital ratios and stability, and Bichsel and Blum (2004), Lindquist (2004), Jokipii and Milne (2008), and Angora et al. (2009) find no or negative relationship between bank capital and performance.
} 
and Adrian and Shin (2014). Myers and Rajan (1998) point to unintended moral hazard effects of asset liquidity: it enables managers to trade assets in their own interest. Our framework points to unintended effects of bank profitability: it enables bankers to borrow more and take more risk in side activities. Adrian and Shin (2014) show that the leverage of financial intermediaries is procyclical: banks can borrow more during upturns, thanks to lower risk weights. Our paper extends their argument, suggesting that the expansion of bank assets during upturns may take form of risky market-based investments, consistent with observations from the financial crisis. ${ }^{4}$

The paper is structured as follows. Section 2 sets up the model. Section 3 solves the model and shows that banks with higher profitability may take more risk. Section 4 endogenizes the cost of funding. Section 5 offers extensions and discusses implications. Section 6 concludes. The proofs are in the Appendix.

\section{The Model}

Consider a bank that operates in a risk-neutral economy with three dates $(0,1,2)$ and no discounting. The bank has no initial capital, has to borrow in order to invest, and maximizes its expected profit.

Projects The bank has four investment opportunities:

1. The banker is endowed with access to a relationships-based "core" project. Thanks to an endowment of private information about the bank's existing customers, the core project is profitable (due to information rents; Petersen and Rajan, 1995) but not scalable (due to adverse selection in the market for new customers, Dell'Ariccia and Marquez, 2006; or the difficulty in processing large amounts of soft information, Stein, 2002). For 1 unit invested at date 0, the core project produces $R>1$ at date 2 . Since the size of the core project is normalized to $1, R$ represents also

\footnotetext{
${ }^{4}$ Another related paper is Boot and Ratnovski (2012) who focus on scope for a misallocation of capital from longterm relationship banking to short-term "trading" activities. Our paper highlights a different issue: how relationship banking profits can be used for risk-shifting in side bank activities.
} 
the profitability of the core project: a ratio of profit to project size. (For simplicity we abstract from risk in the core project. This this does not affect the results. A risky core project is analyzed in Section 5.1.)

2-3. The banker may in addition engage in "side activities" - market-based investments. Market-based investments are scalable but less profitable (due to smaller or absent information rents). ${ }^{5}$ There are two market-based investments. A safe market-based investment (such as treasury securities) for each unit invested at date 1 produces $1+\varepsilon(\varepsilon>0)$ at date 2 . A risky marketbased investment (such as asset-backed securities that stand to lose value in a systemic event) for each unit invested at date 1 produces at date 2: $1+\alpha(\alpha>\varepsilon)$ with probability $p, p<1$, but 0 with probability $1-p$. We denote the scale of the market-based investments $X$. The assumption that market-based investments are initiated after the core project (at date 1 rather than at date 0) captures the observation that market-based investments are undertaken alongside the bank's pre-existing, long-term core business.

4. Finally, the banker can 'abscond'. Immediately after date 1 the owner-manager can convert the bank's assets into private benefits, leaving nothing to creditors. The manager runs the bank normally when:

$$
\Pi \geq b(1+X)
$$

where $\Pi$ is the bank's profit when assets are employed for normal use, and $b(1+X)$ is the initial value of assets $1+X$ multiplied by the conversion factor $b(0<b<1)$ of assets into private benefits. The parameter $b$ can reflect the quality of financial institutions (e.g., creditor rights), with lower $b$ for better institutions. The absconding event is out-of-equilibrium (the creditors do not provide funding if they expect the bank to abscond). The constraint (1) therefore defines the bank's leverage constraint: its maximum balance sheet size as a $1 / b$ multiplier of equity (Holmstrom and Tirole,

\footnotetext{
${ }^{5}$ Banks' traditional lending is indeed usually more profitable than marked-based investments. In 2000-2007, the average bank net interest margin was 3.25\% (NY Fed, 2014) and the average cost of bank funding 3\% (according to the Federal Home Loan Bank of San Francisco Cost of Funds Index), making the gross return on lending 6\%. In the same period, the average gross return on banks' trading assets was only $2 \%$ (during the crisis, the return was negative).
} 
Parametrization Our analysis focuses on the bank's incentives to opportunistically choose a risky rather than safe market-based investment. We assume that the risky market-based investment has a negative NPV:

$$
p(1+\alpha)<1
$$

but once the cost of funding is sunk the expected return to the banker from the risky investment is higher than that from the safe investment, creating incentives for risk-shifting:

$$
p \alpha>\varepsilon \text {. }
$$

The bank's project choice is not verifiable, so the bank cannot commit not to undertake the risky investment. $^{7}$

We also assume that:

$$
R-1 \geq b,
$$

so that the leverage constraint (1) is not binding when the bank engages only in the core project, but:

$$
\varepsilon<p \alpha<b
$$

so that the leverage constraint becomes more binding when the bank expands market-based investments. These conditions can be interpreted as that the core project gives the bank spare borrowing capacity, which can be used for market-based investments. ${ }^{8}$

\footnotetext{
${ }^{6}$ The restriction that firms can borrow only up to a multiple of their net worth is standard in corporate finance models. For banks it can be thought of as an economic capital requirement (Allen et al., 2011). The payoff to moral hazard $b(1+X)$ can represent savings on abstaining from the owner-manager's effort; payoff to absconding, looting, or cash diversion (Calomiris and Kahn, 1991; Akerlof and Romer, 1993; Hart, 1995; Burkart and Ellingsen, 2004; Martin and Parigi, 2013; Boyd and Hakenes, 2014); and more generally result from the limits on the pledgeability of revenues (Holmstrom and Tirole, 1998; Gennaioli et al., 2014).

${ }^{7}$ In practice, some risky market-based investments may be valuable. But we focus on bank incentives to opportunistically undertake value-reducing risky investments. The setup with binary returns to risky investments mimics 'carry trade' strategies that were common in the run-up to the crisis and generated a small positive return most of the time, but catastrophic losses with a small probability (Acharya et al., 2009).

${ }^{8}$ These assumptions are consistent with the observation that traditional banks (with relationship rents and a
} 
Funding The bank funds itself with debt. It attracts 1 unit of funds for the core project at date 0 against the interest rate $r_{0}$, and $X$ units of funds for market-based investments at date 1 against the interest rate $r_{1}$. We call the two groups of creditors "date 0" and "date 1" creditors, respectively.

The creditors are repaid in full at date 2 if the bank is solvent: the payoff from projects exceeds the total amount owed. If the bank is insolvent, which may happen when the risky market-based investment returns 0 , it goes bankrupt and the assets' liquidation value - the core project payoff $R$ - is distributed to the two groups of creditors according to their relative seniority. The relative seniority of date 1 creditors is given by a parameter $\theta$ : the share of their initial investment that they reclaim in bankruptcy. That is, in bankruptcy, date 1 creditors are repaid $\theta X$ and date 0 creditors $R-\theta X$, where $0<\theta<\min \{R / X, 1\}$. A higher $\theta$ implies more senior date 1 creditors.

In the model, we treat $\theta$ as an exogenous parameter. If the bank could choose $\theta$ after date 0 debt is attracted, it would always set the highest possible $\theta$, so as to reduce the cost of date 1 debt. (When the bank funds risky date 1 investments with senior debt, that effectively dilutes the pre-existing claims of date 0 creditors, similar to Brunnermeier and Oehmke, 2013.) Therefore one can interpret the exogenous $\theta$ as the maximum seniority of date 1 debt that is feasible under contractual arrangements available to the bank and its date 1 creditors. (For example, the more of date 1 debt can be attracted as repos, the higher is $\theta.)^{9}$

To generate risk-shifting, we need to impose that some of bank debt is not priced at the margin. That usually reflects environments where bank funding is attracted before the bank's project choice, to which a bank cannot commit in advance. Such an environment is particularly natural in our model, where date 0 funding for the core project might be attracted well ahead of any decisions on market-based side investments. Further, in the main model in Section 3, we assume that $r_{0}=0$.

fixed customer base) are often not capital constrained, while market-based activities require a substantial equity commitment (as obtained through partnerships in early investment banking, or from full partners in hedge funds). A $b$ higher than that in (4), $b>R-1$, would make the bank unable to raise funds even for its core activity. A $b$ lower than that in (5), $b<p \alpha$, would enable the bank to undertake market-based investments on an infinite scale.

${ }^{9}$ The bank may of course want to commit to date 0 creditors to have a low $\theta$. Some firms achieve a degree of commitment to future funding structure e.g., through the use of loan covenants. But for banks such a commitment might be too costly or impossible, due to "frequent funding needs, opaque balance sheets, and continuous activity in the commercial paper market" (Brunnermeier and Oehmke, 2013). 
This allows us to obtain a simple, closed-form solution to the model and demonstrate the economics behind our results most directly. In Section 4 we solve the model with an endogenous $r_{0}$, set based on the date 0 creditors' break-even condition. The intuition remains fully the same. However, allowing endogenous $r_{0}$ necessitates a quantitative solution: we verify that all our results hold for plausible sets of parameter values. Throughout the paper, we let the interest rate $r_{1}$ be priced on the margin, as if date 1 funding comes from informed funding markets that correctly observe the riskiness of the market-based investment undertaken by the bank. ${ }^{10}$

The timeline is summarized in Figure 1.

\section{Solution}

The section solves the model with an exogenous interest rate charged by date 0 creditors: $r_{0}=0$. This simplification streamlines the exposition without affecting the economics of the model. At the same time, we feel that the assumption that the interest rate on "core" bank liabilities (those that underlie the core project) is risk-inelastic is realistic in many environments. For example, this is the case when date 0 creditors are depositors that are protected by deposit insurance with not risk-sensitive premia. ${ }^{11}$ To verify the generality of our results, Section 4 considers a model with an endogenous $r_{0}$ and confirms that our results hold.

\subsection{Bank Strategy}

Consider the bank's choice between a safe and a risky market-based investment. We solve the model backwards: first derive bank profits conditional on bank strategy, then establish the profitmaximizing bank strategy. ${ }^{12}$

\footnotetext{
${ }^{10}$ That is, we assume that bank's risk-taking strategy at date 1 is contemporaneously observable, but is not verifiable, so that it is reflected in date 1 but not date 0 debt contracts. If date 1 debt was not priced on the margin, our results would not change.

${ }^{11}$ See Laeven (2002) for a discussion of deposit insurance modalities. Boyd et al. (1998) and Freixas et al. (2007) analyze mispriced safety net as a source of bank risk-shifting.

${ }^{12}$ Note that the bank always makes at least a safe market-based investment, because it is profitable. Further, the bank only makes a risky investment when its scale is high enough, so that the bank goes bankrupt when the
} 
When, alongside the core project, the bank makes a safe market-based investment, its profit is:

$$
\Pi_{\text {Safe }}=(R-1)+\varepsilon X,
$$

where $R-1$ is the return from the core project, and $\varepsilon X$ is the return from the safe investment, both net of repayment to creditors. (Here $r_{0}=0$ by assumption, and $r_{1}=0$ because the bank with a safe market-based investment never fails.)

When the bank instead makes a risky investment, it goes bankrupt when such investment fails. Its expected profit is:

$$
\Pi_{\text {Risky }}=p\left(R-1+\left(\alpha-r_{1}\right) X\right)
$$

where $p$ is the probability of success of the risky investment, $R-1$ is the return from the core project, and $\left(\alpha-r_{1}\right) X$ is the return to the bank from the risky investment, both net of repayment to creditors. With additional probability $1-p$ the risky investment fails, the bank cannot repay the creditors in full, and the bank's profit is zero. The interest rate $r_{1}$ is obtained from the break-even condition of date 1 creditors:

$$
p\left(1+r_{1}\right) X+(1-p) \theta X=X
$$

where $\left(1+r_{1}\right) X$ is the repayment to date 1 creditors when the risky investment succeeds and the bank is solvent (with probability $p$ ), $\theta X$ is the repayment when the risky investment fails and the bank goes bankrupt (with probability $1-p$ ), and $X$ is the date 1 creditors' initial investment. From (8), the interest rate required by date 1 creditors is:

$$
r_{1}=\frac{(1-p)(1-\theta)}{p}
$$

risky investment fails (i.e., it returns 0). For a smaller scale, when a bank remains solvent upon a 0 realization of risky investment, its shareholders internalize the negative NPV of the risky investment and so would never make it. Finally, a bank never chooses a combination of a safe and a risky market-based investment, because the profit from a combination is dominated by choosing one investment that gives the bank the highest profit. 
making the bank's profit (7):

$$
\Pi_{\text {Risky }}=p\left(R-1+\left(\alpha-\frac{(1-p)(1-\theta)}{p}\right) X\right)
$$

The bank chooses the risky investment when $\Pi_{\text {Risky }}>\Pi_{\text {Safe }}$, corresponding to:

$$
X>X_{\min }=\frac{(1-p)(R-1)}{p \alpha-\varepsilon-(1-p)(1-\theta)},
$$

where:

$$
\theta>\theta^{*}=1-\frac{p \alpha-\varepsilon}{1-p}
$$

and never for a lower $\theta$. That is, the bank makes the risky investment when two conditions hold. First, the seniority of new debt is high enough, so that financing the risky investment is sufficiently cheap. Second, the scale of the risky investment is large enough. The intuition is that undertaking a risky investment has a fixed cost: the loss of profits from the core project in bankruptcy with probability $1-p$. At the same time, the benefit of the risky investment - its higher return - is proportional to the scale of the market-based investment $X{ }^{13}$

Now consider the bank's ability to lever up to undertake the risky investment. The leverage constraint (1) of a bank that undertakes the risky investment at scale $X$ is:

$$
p\left(R-1+\left(\alpha-\frac{(1-p)(1-\theta)}{p}\right) X\right) \geq b(1+X)
$$

where the left hand side is the bank's profit (same as $\Pi_{\text {Risky }}$ in (10)) and $b(1+X)$ is the absconding payoff. This gives the maximum scale of the risky investment consistent with the bank's leverage constraint:

$$
X \leq X_{\max }=\frac{p(R-1)-b}{b-p \alpha+(1-p)(1-\theta)}
$$

\footnotetext{
${ }^{13}$ It is easy to verify that $X_{\min }>R-1$, where $R-1$ is the minimum scale of the risky investment such the the bank becomes insolvent when it returns 0 . Indeed, from $(2)$ : $(1-p)-p \alpha>0>-\varepsilon-(1-p)(1-\theta)$, implying that $X_{\min }>R-1$.
} 
We can now summarize the bank's strategy as follows:

Lemma 1 The bank chooses a risky market-based investment when $\theta>\theta^{*}$ and $X_{\min }<X_{\max }$. The interval $\left(X_{\min }, X_{\max }\right]$ is non-empty when the bank's leverage constraint is sufficiently lax:

$$
b<b^{*}=\frac{(p(\alpha-\varepsilon)-(1-p)(1-\theta))(R-1)}{(1-p)(R-1)+p \alpha-\varepsilon-(1-p)(1-\theta)} .
$$

Whenever the bank makes the risky investment, it does so at its maximum possible scale $X_{\max }$, since $\partial \Pi_{\text {Risky }} / \partial X>0$.

Proof. See Appendix A.

The intuition for Lemma 1 is that a value-reducing risky investment is only attractive to the bank when it has sufficient scale and is funded with cheap senior debt. Lax leverage constraint a low $b$ - may be a result of better financial institutions with more protection of creditor rights. This interpretation is consistent with the fact that banks in advanced economies were on average more leveraged and more exposed to investments in untested financial products compared to banks

in emerging and developing economies prior to the recent crisis (Claessens et al., 2010). The availability of senior funding for market-based investments - a high enough $\theta$ - may relate to access to secured (repo) funding. For $b \geq b^{*}$ or $\theta \leq \theta^{*}$ the bank chooses the safe market-based investment.

\subsection{Bank Risk-Taking}

We can now establish how the bank's core profitability $R$ affects its risk-taking. We can demonstrate the following result:

Proposition 1 (Bank Profitability and Risk-Taking) Higher profitability of the bank's core business $R$ expands the range of parameter values for which the bank undertakes the risky investment: $\partial b^{*} / \partial R>0$, and increases the scale of the risky investment: $\partial X_{\max } / \partial R>0$.

Proof. See Appendix A. 
Proposition 1 is our key result. It shows that banks with a more profitable core business may have higher risk-taking incentives - choose the risky market-based investment for a wider range of parameter values. The intuition is that higher core profitability allows the bank to make the risky investment on a larger scale (higher $X_{\max }$ ), and this may offset lower incentives to take risk of given size (higher $\left.X_{\min }\right){ }^{14}$ This result sheds light on the reasons why some profitable banks invested so much in risky, untested financial instruments before the recent crisis. High profitability allowed those banks to take risky side exposures on an exceedingly large scale, which compensated for the risk of a loss of a profitable core business franchise. Figure 2 panel A illustrates the impact of the bank's core profitability $R$ on its risk-taking in side activities.

We further ask how the feasible seniority of date 1 funding $\theta$ affects bank risk-taking. We can demonstrate the following result:

Proposition 2 (Debt Seniority and Bank Risk-Taking) Higher seniority of date 1 funding $\theta$ expands the range of parameter values for which the bank undertakes the risky investment: $\partial b^{*} / \partial \theta>$ 0 , and increases the scale of the risky investment: $\partial X_{\max } / \partial \theta>0$. Moreover, the effects of core business profitability and debt seniority on bank risk-taking are mutually reinforcing: $\partial^{2} b^{*} / \partial R \partial \theta>$ 0 and $\partial^{2} X_{\max } / \partial R \partial \theta>0$.

\section{Proof. See Appendix A.}

Proposition 2 highlights the role of bank funding arrangements in inducing risk-shifting through side activities. When side activities (market-based investments) are financed with senior funding, this subsidizes new, date 1 creditors at the expense of incumbent, date 0 creditors. The interest rate required by the new creditors declines in their seniority: $\partial r_{1} / \partial \theta=-(1-p) / p<0$, making side investments more attractive. Since the feasible scale of side investments $X$ (on which the interest rate subsidy is accrued) increases in $R$, the effects of higher core profitability and new debt seniority on bank risk-taking are mutually reinforcing. Figure 2 panel B illustrates the impact of new bank debt seniority $\theta$ on bank risk-taking.

\footnotetext{
${ }^{14}$ From $(11)$ and $(12): \partial X_{\min } / \partial R=(1-p) /(p \alpha-\varepsilon-(1-p)(1-\theta))>0$.
} 


\section{Solution with an Endogenous $r_{0}$}

In the previous section we held $r_{0}=0$ to obtain simple, closed-form results and demonstrate the economics of our model most directly. That section also discussed why an exogenous cost of long-term funding might be a valid descriptive assumption in practice. This section considers an endogenous $r_{0}$ set from the date 0 creditors' break-even condition, and verifies that the results of Propositions 1 and 2 hold.

With an endogenous $r_{0}$ the solution becomes more complex. The reason is the interaction between the interest rate charged by date 0 creditors and bank risk-taking. The bank's anticipated risk-taking implies a positive interest rate $r_{0}$. In a typical risk shifting model, a higher $r_{0}$ makes the bank less profitable and increases its risk-taking, validating a higher interest rate charged in the first place. But in our model a higher interest rate $r_{0}$ may reduce bank risk-taking. The reason is that a higher $r_{0}$ implies a lower profitability of the core project, which reduces the bank's borrowing capacity, and lowers its incentives to take risk in side activities. ${ }^{15}$ As we will see, it is always possible in our model to choose $r_{0}$ high enough to prevent bank risk-taking. But for a sufficiently high bank profitability $R$ this "risk-mitigating" interest rate might be higher than the interest rate that internalizes bank risk-taking. Also, with the "risk-mitigating" interest rate date 0 bank creditors generally obtain positive rents. To meaningfully characterize the equilibrium, we assume that date 0 creditors set the minimal interest rate such that they at least break even under correctly anticipated bank risk choices. (The assumption of a minimal interest rate is consistent with competitive creditors.)

\subsection{Interest Rates and Bank Strategy}

We ask what are the consistent combinations of date 0 interest rates and bank risk choices. There are three such possible combinations in our model.

\footnotetext{
${ }^{15}$ The idea that a higher interest rate may reduce bank risk-taking because it constrains the bank's leverage has a flavor of discussions on the search for yield in the environment of low interest rates. Section 5 explores the effects of monetary policy and related interest rates environment in our model in more detail.
} 
1. A bank has no risk-taking incentives. Assume that date 0 creditors anticipate that the bank will choose a safe market-based investment and set $r_{0}=0$. As in the basic model, this is only possible for $b>b^{*}$ (see (15)). For $b<b^{*}$, date 0 creditors have to set a positive interest rate, anticipating risk-shifting in response to a zero interest rate.

2. A bank takes risk. Now consider the case when date 0 creditors anticipate that the bank will make a risky market-based investment. In this case, they set the interest rate $r_{0}$ based on the zero-profit condition:

$$
p\left(1+r_{0}\right)+(1-p)(R-\theta X)=1
$$

where $\left(1+r_{0}\right)$ is the repayment to date 0 creditors when the risky investment succeeds and the bank is solvent (with probability $p),(R-\theta X)$ is the repayment when the risky investment fails and the bank goes bankrupt (with probability $1-p$ ), and 1 is the date 0 creditors' initial investment. Further, the creditors know that in equilibrium the bank takes the market-based investment on the maximum possible scale, giving (similar to (14)):

$$
X=X_{\max }\left(r_{0}\right)=\frac{p\left(R-\left(1+r_{0}\right)\right)-b}{b-p \alpha+(1-p)(1-\theta)}
$$

Substituting $X$ from (17) and solving (16) for $r_{0}$ obtains the interest rate $r_{0}^{\text {Risky }}$ that date 0 creditors set when they anticipate bank risk-taking in side activities:

$$
r_{0}^{\text {Risky }}=\frac{1-p}{p} \cdot \frac{(R-1)(\theta-(b-p \alpha+1-p))-b \theta}{b-p \alpha+1-p} .
$$

It is easy to verify that $r_{0}^{R i s k y}>0$ for $b=b^{*}$ and $\partial r_{0}^{R i s k y} / \partial b<0$.

3. Bank risk-taking is mitigated by a sufficiently high $r_{0}$. Now consider the effects of a higher interest rate $r_{0}$ on bank risk-taking. Consider $b<b^{*}$, so that the bank would take risk in response to $r_{0}=0$. Note that the increase in $r_{0}$ decreases the bank's borrowing capacity (from (17): $\left.\partial X_{\max }\left(r_{0}\right) / \partial r_{0}<0\right)$ and therefore its ability to take risk in market-based investments. Indeed, for 
any $b<b^{*}$ there exists $r_{0}^{\text {Risk-mitigating }}(b)>0$ such that in response to that interest rate the bank does not take risk. To derive $r_{0}^{\text {Risk-mitigating }}$, consider the minimal profitable scale of the risky market-based investment $X_{\min }($ similar to $(11)$ ):

$$
X_{\min }\left(r_{0}\right)=\frac{(1-p)\left(R-\left(1+r_{0}\right)\right)}{p \alpha-\varepsilon-(1-p)(1-\theta)},
$$

and set $X_{\min }\left(r_{0}\right)=X_{\max }\left(r_{0}\right)$ (use $\left.(17)\right)$ to obtain:

$$
r_{0}^{\text {Risk-mitigating }}=(R-1)-\frac{b(p \alpha-\varepsilon-(1-p)(1-\theta))}{p(\alpha-\varepsilon)-(1-p)(1-\theta)-(1-p) b} .
$$

Note that $r_{0}^{\text {Risk-mitigating }}=0$ for $b=b^{*}$ and $\partial r_{0}^{\text {Risk-mitigating }} / \partial b<0$.

\subsection{Equilibrium}

Recall that date 0 creditors choose the minimal interest rate consistent with at least breaking even under correctly anticipated bank risk-taking strategy. For $b>b^{*}$ that is $r_{0}=0$. For $b<b^{*}$ that is either $r_{0}^{\text {Risk-mitigating }}$ or $r_{0}^{\text {Risky }}$, whichever is lower. Unfortunately, the closed-form solution to $r_{0}^{\text {Risk-mitigating }}=r_{0}^{\text {Risky }}$ is too complex to be tractable. Therefore, from this point on we need to examine the model quantitatively.

A quantitative exercise needs to be carefully interpreted. Any quantitative exercise demonstrates the existence of parameter values for which model insights hold, not the generality of the findings. There are two ways to reflect on this limitation. First, the purpose of this paper is to show that certain effects may exist rather than that they hold universally. In this context, a quantitative exercise confirms the existence of our results - that bank risk-taking can increase in the profitability of its core business as well as in the feasible seniority of its new funding (as in Propositions 1 and 2) - for a plausible set of parameter values. Second, we studied multiple variations of parameter values and the results of the model hold consistently across them. This suggests a degree of generality of the quantitative results. 
We first characterize equilibrium combinations of date 0 interest rate $r_{0}$ and bank risk-taking choices, depending on the intensity of the leverage constraint $b$. Figure 3 panel A illustrates the evolution of $r_{0}^{\text {Risk-mitigating }}$ and $r_{0}^{\text {Risky }}$ in $b$ for the following headline set of parameter values: $R=1.07 ; \varepsilon=0.02 ; \alpha=0.03 ; p=0.97 ; \theta=0.75$. In addition to this set, we examined alternative sets of parameter values that cover a substantial range of their plausible values and obtained similar results. ${ }^{16}$ The following summarizes:

Quantitative result 1. Equilibrium date 0 interest rate and bank risk-taking are characterized by two thresholds: $b^{*}$ (as in (15)) and $b^{* *}$ obtained from solving $r_{0}^{\text {Risk-mitigating }}=r_{0}^{\text {Risky }}$, as follows:

- For $b \geq b^{*}$, date 0 creditors set $r_{0}=0$, and the bank chooses the safe market-based investment.

Date 0 creditors break even.

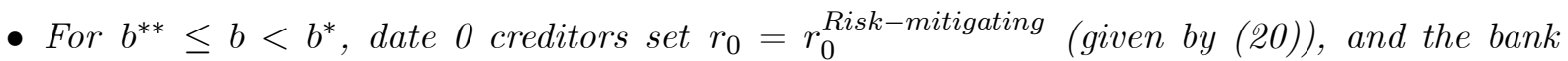
chooses the safe market-based investment. Date 0 creditors earn positive rents, but a lower interest rate would induce the bank to take risk and thus violate the date 0 creditors' break-even condition.

- For $b<b^{* *}$, date 0 creditors set $r_{0}=r_{0}^{\text {Risky }}$ (given by (18)), and the bank chooses the risky market-based investment.

The intuition is as follows. As $b$ declines below $b^{*}$, the bank would choose a risky investment in response to $r_{0}=0$. Yet a small increase in the date 0 interest rate from $r_{0}=0$ to $r_{0}=r_{0}^{\text {Risk-mitigating }}$ can prevent bank risk-taking (recall that $r_{0}^{\text {Risk-mitigating }} \rightarrow 0$ for $b \rightarrow b^{*}$ ). Interestingly, for $b^{* *} \leq b<b^{*}$, date 0 creditors earn positive rents. Yet $r_{0}^{\text {Risk-mitigating }}$ is the smallest interest rate consistent with them at least breaking even: reducing the interest rate would induce bank risk-taking and make date 0 creditors lose money on expectation. As $b$ declines further, the

\footnotetext{
${ }^{16}$ The sets were: $R \in[1.05 ; 1.15]$ to reflect return on bank loans; $\varepsilon \in[0.01 ; 0.05]$ to reflect 10 -year treasury interest rates; $\alpha \in[0.02 ; 0.10]$ to reflect $\mathrm{ABS}$ or bond yields; $p \in[0.95 ; 0.98]$ to reflect $\mathrm{ABS}$ or bond risk; $\theta \in[0.75 ; 0.95]$ to reflect substantial use of senior (e.g., repo) funding for market-based investments. We used those combinations of parameter values from these sets that satisfied conditions (2)-(5).
} 
"risk-mitigating" interest rate increases. At $b=b^{* *}$ it becomes cheaper to price risk-taking rather than to mitigate it. Thus, for $b<b^{* *}$, date 0 creditors charge $r_{0}^{\text {Risky }}$ and break even, while the bank makes the risky investment. ${ }^{17}$

The key implication of Quantitative result 1 is that the threshold value of $b$ at which bank takes risk is not anymore $b^{*}$ as was under an exogenous $r_{0}=0$ in Section 3 , but rather $b^{* *}<b^{*}$. The reason for a lower threshold is that allowing $r_{0}$ to be endogenous and positive reduces the bank's core profitability and therefore its risk-taking incentives. Accordingly, a bank makes a risky rather than safe market-based investment only for a narrower range of parameter values.

\subsection{Bank Risk-Taking}

We can now characterize how the threshold $b^{* *}$ (such that the bank takes risk for $b<b^{* *}$ ) responds to changes in $R$ and $\theta$. Similar to before, we report the results of the quantitative exercise for the following headline set of parameter values: $\varepsilon=0.02 ; \alpha=0.03 ; p=0.97$. We examined alternative sets of parameter values and obtained similar results. Figure 3 panel B illustrates the evolution of $b^{* *}$ in $R$ and $\theta$. The following summarizes:

Quantitative result 2. The threshold $b^{* *}$ increases in $R$ and $\theta$, and is convex in the combination of $R$ and $\theta$.

The evolution of $b^{* *}$ in response to $R$ and $\theta$ is similar to the evolution of $b^{*}$ as in Propositions 1 and 2. Banks take risk for a wider range of parameter values when their core profitability $R$ is higher, as well as when the feasible seniority of debt used to finance market-based investments $\theta$ is higher. The results of the quantitative exercise therefore confirm that the results of Propositions 1 and 2 exist and appear to be robust for plausible sets of parameter values under an endogenous date 0 interest rate $r_{0}$. The intuition, again, is that higher profitability boosts the bank's ability to

\footnotetext{
${ }^{17}$ Note that $r_{0}^{\text {Risky }}=r_{0}^{\text {Risk-mitigating }}$ is a quadratic equation in $b$. The threshold $b^{* *}$ is the larger root of that equation. Within our parameter values, the other root is always below $p \alpha$, which is the lowest value of $b$ consistent with the parameters of our model (see (5)).
} 
borrow. A more profitable bank can take risky side projects on an exceedingly larger scale, which offsets its lower incentives to take risk of given size.

\section{Extensions}

This section offers three extensions to the model. First, we consider a non-deterministic core project and let the bank exert effort to improve its performance. We show that access to an opportunistic market-based investment may induce the bank to increase its effort in the core project, because a more valuable core project enables the bank to pursue side investments on a larger scale. A bank then strategically combines a prudent core project with a risky market-based investment.

Second, we consider the effects of changes in bank funding costs (as might be driven by monetary policy) on bank risk taking in its core business versus in market-based investments. We show that a reduction in a bank's cost of funding may induce higher effort in the core project, but at the same time more risk-taking in market-based activities. The reason is that a lower cost of funding is akin to a more profitable core project. It makes a bank less willing to take risk in the core project to preserve its value, but enables the bank to lever up and take more risk in side activities. This finding highlights possible differential effects of monetary policy on bank risk-taking depending on the type of bank activity.

Third, we introduce into the model explicit bank capital, and show its effects in the model are equivalent to those of bank profitability. This establishes a link between our paper and empirical literature on bank capital and risk-taking.

To simplify exposition, we go back to the assumption of exogenous date 0 interest rate: $r_{0}=0$. (Endogenizing $r_{0}$ would not affect the results.) 


\subsection{Effort in the Core Project}

Consider the case where the return on the core project is no longer deterministic. Instead, the bank needs to exert effort to improve the performance (increase the probability of success) of the core project. We analyze how access to an opportunistic market-based investment may affect bank incentives in the core project.

Assume that the return on the core project is $R$ with probability $e$ and 0 otherwise (as opposed to a certain $R$ in the main model). The probability $e$ corresponds to the bank's effort, which carries a private cost $c e^{2} / 2$. We focus on $c$ high enough such that the model admits an interior solution in effort. The bank exerts effort after date 0 funding is attracted. The outcome of the effort becomes known immediately afterwards. If it becomes known that the core project returns 0 , the bank goes bankrupt (it cannot make market-based investments either because the leverage constraint (1) is not satisfied). If it becomes known that the core project returns $R$, the rest of the game is similar to the model in Section 3. The timeline is summarized in Figure 4.

We are interested in two questions. First, how the bank's effort in the core project $e$ depends on its ability to complement the core project with market-based side investments, as captured by $b$ (a lower $b$ meaning a laxer leverage constraint and more scope for side investments). Second, how effort $e$ is affected by the bank's access to an opportunistic, risky market-based investment, compared to a hypothetical case when the bank only had access to a safe market-based investment.

When the core project produces 0 , the payoff to bankers is also 0 . When the core project

produces $R$, the bank chooses a safe market-based investment for $b \geq b^{*}$ (with $b^{*}$ given in (15)) and a risky one for $b<b^{*}$. For $b \geq b^{*}$, the bank's profit is:

$$
\Pi_{\text {Safe }}^{e}=e(R-1+\varepsilon X)-\frac{c e^{2}}{2}
$$

where $(R-1+\varepsilon X)$ is the bank's profit conditional on successful effort (similar to (6)), $e$ is the probability of success, and $-c e^{2} / 2$ is the cost of effort. The scale of the market-based investment 
$X$ is obtained by setting to equality the leverage constraint (1) that takes form:

$$
R-1+\varepsilon X \geq b(1+X),
$$

giving: $X=(R-1-b) /(b-\varepsilon)$. Substituting $X$ from (22) into $\Pi_{\text {Safe }}^{e}(21)$ and maximizing with respect to $e$ gives:

$$
e_{\text {Safe }}^{*}=\frac{b}{c} \cdot \frac{R-1-\varepsilon}{b-\varepsilon}
$$

For $b<b^{*}$, the bank' profit is:

$$
\Pi_{\text {Risky }}^{e}=e p\left(R-1+\left(\alpha-\frac{(1-p)(1-\theta)}{p}\right) X\right)-\frac{c e^{2}}{2}
$$

where $p(\cdot)$ is the bank's profit conditional on successful effort (similar to (10)). Deriving $X$ and maximizing $\Pi_{\text {Risky }}^{e}$ in a manner similar to (23) gives effort:

$$
e_{\text {Risky }}^{*}=\frac{b}{c} \cdot \frac{p(R-1-\alpha)+(1-p)(1-\theta)}{b-p \alpha+(1-p)(1-\theta)} .
$$

It is easy to obtain by differentiation of (23) and (25) that the bank's effort increases in the profitability of the core project: $\partial e_{\text {Safe }}^{*} / \partial R>0$ and $\partial e_{\text {Risky }}^{*} / \partial R>0$. A higher return on the core project naturally induces more effort to make it succeed. More interesting, the bank's effort in the core project also increases with the bank's ability to make market-based investments: $\partial e_{S a f e}^{*} / \partial b<0$ and $\partial e_{\text {Risky }}^{*} / \partial b<0$, with a lower $b$ capturing a higher feasible scale of risky investments. The intuition is that success in the core project enables the bank to make market-based investments, and profit from these investments increases in their feasible scale.

We can now undertake the following exercise. Consider $b<b^{*}$, so that the bank chooses the risky market-based project investment when the core project succeeds. Compare this with the case when the bank is restricted to the safe market-based project only. We can demonstrate the following result: 
Proposition 3 (Safe Core Business, Risky Side Investments) For $b<b^{*}$, the bank's effort when the risky market-based investment is available is higher than the bank's effort when the bank is restricted to the safe market-based investment only: $\left.e_{\text {Risky }}^{*}\right|_{b<b^{*}}>\left.e_{\text {Safe }}^{*}\right|_{b<b^{*}}$.

\section{Proof. See Appendix A.}

Although the risky market-based investment has a negative NPV, after date 0 debt is attracted and for $b<b^{*}$ this investment becomes ex post more profitable for bank shareholders than the safe market-based investment (this is the essence of risk-shifting). Accordingly, the bank increases its effort in the core project in order to ensure its ability to undertake a privately-profitable risky market-based investment. The bank strategically combines a safe core project with risky side activities. While the literature has often associated such seeming inconsistency in bank strategy with a "clash of cultures" between conservative bankers and risk-loving traders (Froot and Stein, 1998), our model allows us to explain it based purely on shareholder value maximization under the possibility of risk-shifting in side activities.

\subsection{Monetary Policy and Bank Risk-Taking}

Now consider the case where the bank's cost of funding can exogenously vary. We associate the variance in bank funding costs to changes in the monetary policy stance, which targets short-term rates, and thus affects banks primarily through the cost of funding. ${ }^{18}$ Instead of requiring expected return of 0 as in the main model, assume that bank creditors require expected return of $i$. We keep the cost of date 0 debt exogenous, $r_{0}=i$. The cost of date 1 debt is priced at the margin and determined by the new break-even condition with the reservation return $i$. When the bank makes the safe market-based investment, $r_{1}=i$. When the bank makes the risky investment, the break-even condition (similar to (8)) is:

$$
p\left(1+r_{1}\right) X+(1-p) \theta X=(1+i) X,
$$

\footnotetext{
${ }^{18}$ Monetary policy may also affect returns on bank assets. We abstract from these effects. To an extent that bank liabilities are short-term while bank asset are long-term, the impact of monetary policy that targets the short-term interest rate is more significant for bank liabilities than for bank assets (Dell'Ariccia et al., 2014).
} 
which gives (similar to $(9))$ :

$$
r_{1}=\frac{i+(1-p)(1-\theta)}{p}
$$

With the cost of funding $i$, the threshold for the choice of safe versus risky market-based investment $b_{i}^{*}($ similar to $(15))$ becomes:

$$
b_{i}^{*}=\frac{(R-1-i)(p(\alpha-\varepsilon)-(1-p)(1-\theta+i))}{(1-p)(R-1-i)+p \alpha-\varepsilon-(1-p)(1-\theta)} .
$$

And the equilibrium levels of effort in the core project (similar to (23) and (25)) become:

$$
\begin{aligned}
e_{\text {Safe }, i}^{*} & =\frac{b}{c} \cdot \frac{R-1-\varepsilon}{b-\varepsilon+i} \text { for } b \geq b^{*}, \text { and } \\
e_{\text {Risky }, i}^{*} & =\frac{b}{c} \cdot \frac{p(R-1-i)-p \alpha+i+(1-p)(1-\theta)}{b-p \alpha+i+(1-p)(1-\theta)} \text { for } b<b^{*} .
\end{aligned}
$$

Differentiation of (28)-(30) obtains the following result:

Proposition 4 (Monetary Policy and Bank Risk-Taking) A decrease in the bank's cost of funding increases the bank's effort in the core project, making it safer: $\partial e_{\text {Safe, },}^{*} / \partial i<0$ and $\partial e_{\text {Risky, } i}^{*} / \partial i<0$; but at the same time makes the bank more likely to take risk in market-based investments: $\partial b_{i}^{*} / \partial i<0$.

Proof. See Appendix A.

Proposition 4 suggests a novel heterogeneity in the possible impact of monetary policy on bank risk-taking. A lower cost of funding (corresponding to more accommodative monetary policy) increases bank margins. For those bank activities that have fixed scale, such as the core relationships-based business, higher margins induce higher effort. But for scalable bank activities, such as market-based side investments, higher margins make the leverage constraint less binding, allowing the bank to borrow more. The bank increases the scale of market-based investments, boosting the incentives to use such investments for risk-shifting.

The fact that accommodative monetary policy may differently affect bank risk-taking in the core 
business versus in side investments suggests that the impact of monetary policy on bank risk may depend on the bank's mix of activities. For example, accommodative monetary policy may induce risk-taking relatively less in small banks involved in relationship lending, but relatively more in large banks active in financial markets (cf. Borio and Zhu, 2012). This finding complements other heterogeneities in the impact of monetary policy on bank risk-taking identified in the literature (e.g., those relating to banks' leverage and interbank competition, as in Dell'Ariccia et al., 2014).

\subsection{Bank Capital}

As a final extension, we examine the possible role of explicit bank capital in our model. In the model so far, the bank was financed entirely with debt and derived implicit equity from the NPV of its core project. One can introduce into the model explicit equity by assuming that at date 0 the owner-manager is endowed with wealth $k<1$ that she invests into the bank as equity, and finances the rest $(1-k$ for the core project and $X$ for the market-based investment) with debt.

Allowing explicit equity would not affect the results of the model. In fact, in this model explicit equity is a perfect substitute for implicit equity derived from the NPV of the bank's core project. That is, more explicit equity is fully equivalent to higher bank profitability. To see this, go back to

the model of Section 3. With explicit equity, one can rewrite thresholds $X_{\min }$ and $X_{\max }((11)$ and (14)) as:

$$
\begin{aligned}
X_{\min }^{k} & =\frac{(1-p)(R-1+k)}{p \alpha-(1-p)(1-\theta)-\varepsilon}, \text { and } \\
X_{\max }^{k} & =\frac{p(R-1+k)-b(1-k)}{b-p \alpha+(1-p)(1-\theta)}
\end{aligned}
$$

and the threshold $b^{*}(15)$ as:

$$
b_{k}^{*}=\frac{(p(\alpha-\varepsilon)-(1-p)(1-\theta))(R-1+k)}{(1-p)(R-1+k)+(1-k)(p \alpha-\varepsilon-(1-p)(1-\theta))} .
$$

Note that capital only enters the expressions as a sum with bank profitability $R-1$. This is 
not surprising. Both represent shareholder value at stake. An increase in $k$ has identical impact on model outcomes as an increase in core profitability $R-1$. Accordingly, one can show that $\partial b_{k}^{*} / \partial k>0$ : an increase in explicit bank capital increases bank risk-taking incentives by increasing the bank's ability to borrow (similar to the effect of bank profitability in Proposition 1). All other effects naturally also persist with explicit bank capital.

\section{Conclusions}

This paper studied risk-taking incentives in banks. Traditional Jensen and Meckling (1976) intuition suggests that more profitable banks should have lower risk-taking incentives. But during the recent crisis many profitable financial institutions seemed particularly exposed to risks from untested financial instruments. We attempt to reconcile theory and evidence by highlighting that many banks today are organized around a stable core business, and take risk by levering up to make risky market-based instruments. High profitability allows a bank to borrow more and engage in side investments on a larger scale. This can offset lower incentives to take risk of given size. Consequently, more profitable banks may have higher, rather than lower, risk-taking incentives. We also show that banks take more risk when the side investments can be financed with senior funding (e.g., repos), and in countries with better protection of creditor rights (where banks can increase leverage more). Banks may strategically combine high effort in the core business with opportunistic risk-taking in market-based activities. Accommodative monetary policy may make core bank activities safer while risk-taking in market-based investments more acute. Overall, the description of bank risk-taking as occurring in side activities, as well as the cross-sectional patterns of bank risk-taking predicted by the model, seem to conform well with the patterns of bank risktaking in the run-up to the recent crisis.

The key lesson from the paper is that higher bank profitability (or, similarly, higher bank franchise value or bank capital) is not panacea against risk-taking. Profitable banks have superior capacity to borrow and therefore can rapidly accumulate risks. ${ }^{19}$ (In fact, they may have strong

\footnotetext{
${ }^{19}$ This observation has interesting implications for the relationship between interbank competition and financial
} 
incentives to do so, in line with the practitioners' assertions that banks face pressure to "put to risk" their "unused" capital.) Bank risk-taking should be understood as a dynamic concept. Regulators need to consider not only contemporaneous bank risks, but also the ability of a bank to increase risk going forward. Such "dynamic" effects are particularly relevant when banks have easy access to scalable market-based investments. As financial markets have deepened (Morrison and Wilhelm, 2007; Boot, 2014), the ability of banks to quickly accumulate large-scale exposures has amplified. Accordingly, the concerns about the risk-taking of profitable banks through their side activities that are highlighted by our study may have recently become particularly pertinent.

stability. Banks that are less exposed to competition in the core business are more profitable, and thus may take more risk in their side activities. This channel complements other papers that argue that insufficient interbank competition may compromise financial stability (Boyd and De Nicolo, 2005; Carlson and Mitchener, 2006; Hufner, 2010; Calomiris and Haber, 2013; Akins et al., 2014). 


\section{References}

[1] Acharya, Viral V., Thomas Cooley, Matthew Richardson, and Ingo Walter (2009), Manufacturing Tail Risk: A Perspective on the Financial Crisis of 2007-2009, Foundations and Trends in Finance, 4(4), 247-325.

[2] Acharya, Viral V. and T. Sabri Öncü (2013), A Proposal for the Resolution of Systemically Important Assets and Liabilities: The Case of the Repo Market, International Journal of Central Banking, 9, 291-349.

[3] Acharya, Viral V. and Matthew Richardson (2009), Restoring Financial Stability: How to Repair a Failed System?, John Wiley \& Sons.

[4] Adrian, Tobias and Hyun Song Shin (2014), Procyclical Leverage and Value-at-Risk, Review of Financial Studies, 27(2), 373-403.

[5] AIG [American International Group], 2008, Annual Report.

[6] Akerlof, George A. and Paul M. Romer (1993), Looting: The Economic Underworld of Bankruptcy for Profit, Brookings Papers on Economic Activity, 2, 1-73.

[7] Akins, Brian, Lin Li, Jeffrey Ng, and Tjomme O. Rusticus (2014), Bank Competition and Financial Stability: Evidence from the Financial Crisis, Journal of Financial and Quantitative Analysis, forthcoming.

[8] Allen, Franklin, Elena Carletti, and Robert Marquez (2011), Credit Market Competition and Capital Regulation, Review of Financial Studies, 24(4), 983-1018.

[9] Angora, Alain, Isabelle Distinguin, and Clovis Rugemintwari (2009), Excess Capital of European Banks: Does Bank Heterogeneity Matter?, Working Paper University of Limoges.

[10] Barth, James, Gerard Caprio, and Ross Levine (2006), Rethinking Bank Regulations: Till Angels Govern, Cambridge University Press. 
[11] Beltratti, Andrea and Rene M. Stultz (2012), The Credit Crisis Around the Globe: Why Did Some Banks Perform Better?, Journal of Financial Economics, 105, 1-17.

[12] Berger, Allen N. and Christa H.S. Bouwman (2013), How Does Capital Affect Bank Performance During Financial Crises?, Journal of Financial Economics, 109, 146-176.

[13] Bichsel, Robert and Jurg Blum (2004), The Relationship Between Risk and Capital in Swiss Commercial Banks: A Panel Study, Applied Financial Economics, 14, 591-597.

[14] Blum, Jurg (1999), Do Capital Adequacy Requirements Reduce Risks in Banking?, Journal of Banking and Finance, 23, 755-771.

[15] Boot, Arnoud W.A. (2014), Financial Sector in Flux, Journal of Money, Credit, and Banking, 46(1), 129-135.

[16] Boot, Arnoud W.A. and Lev Ratnovski (2012), Banking and Trading, IMF Working Paper $12 / 238$.

[17] Borio, Claudio and Haibin Zhu (2012), Capital Regulation, Risk-Taking and Monetary Policy: A Missing Link in the Transmission Mechanism?, Journal of Financial Stability, 8(4), 236-251.

[18] Boyd, John H., Chun Chang, and Bruce.D. Smith (1998), Moral Hazard under Commercial and Universal Banking, Journal of Money, Credit and Banking, 30(3), 426-468.

[19] Boyd, John H. and Gianni De Nicolo (2005), The Theory of Bank Risk Taking and Competition Revisited, Journal of Finance, 60(3), 1329-1343.

[20] Boyd, John H. and Hendrik Hakenes (2014), Looting and Risk Shifting in Banking Crises, Journal of Economic Theory, 149, 43-64.

[21] Brunnermeier, Marcus and Martin Oehmke (2013), Maturity Rat Race, Journal of Finance, $68(2), 483-521$.

[22] Burkart, Mike and Tore Ellingsen (2004), In-Kind Finance: A Theory of Trade Credit, American Economic Review, 94(3), 569-590. 
[23] Calem, Paul and Rafael Rob (1999), The Impact of Capital-Based Regulation on Bank Risk Taking, Journal of Financial Intermediation, 8, 317-352.

[24] Calomiris, Charles and Stephen H. Haber (2013), Fragile by Design: The Political Origins of Banking Crises and Scarce Credit, Princetown University Press.

[25] Calomiris, Charles V. and Charles M. Kahn (1991), The Role of Demandable Debt in Structuring Optimal Bank Arrangements, American Economic Review, 3, 497-513.

[26] Camara, Boubacar, Lepetit, Laetitia, and Amine Tarazi (2013), Ex Ante Capital Position, Changes in the Different Components of Regulatory Capital and Bank Risk, Applied Economics, 45(34), 4831-4856.

[27] Carlson, Mark and Kris James Mitchener (2006), Branch Banking, Bank Competition, and Financial Stability, Journal of Money, Credit, and Banking, 38(5), 1293-1328.

[28] Claessens, Stijn, Giovanni Dell'Ariccia, Deniz Igan, and Luc Laeven (2010), Cross-Country Experiences and Policy Implications from the Global Financial Crisis, Economic Policy, 25(62), 267-293.

[29] Dell'Ariccia, Giovanni, Luc Laeven, and Robert Marquez (2014), Real Interest Rates, Leverage, and Bank Risk-Taking, Journal of Economic Theory, 149, 65-99.

[30] Dell'Ariccia, Giovanni, Luc Laeven, and Gustavo Suarez (2013), Bank Leverage and Monetary Policy's Risk-Taking Channel: Evidence from the United States, IMF Working Paper 13/143.

[31] Dell'Ariccia, Giovanni and Robert Marquez (2006), Lending Booms and Lending Standards, Journal of Finance, 61(5), 2511-546.

[32] Demsetz, Rebecca, Mark R. Saidenberg, and Philip E. Strahan (1996), Banks with Something to Lose: The Disciplinary Role of the Franchise Value, Federal Reserve Bank of New York Economic Policy Review, 2(2), 1-14. 
[33] Freixas, Xavier, Gyöngyi Lóránth, and Alan D. Morrison (2007), Regulating Financial Conglomerates, Journal of Financial Intermediation, 16(4), 479-514.

[34] Froot, Kenneth A. and Jeremy C. Stein (1998), Risk Management, Capital Budgeting, and Capital Structure Policy for Financial Institutions: An Integrated Approach, Journal of Financial Economics, 47, 55-82.

[35] Gennaioli, Nicola, Alberto Martin, and Stefano Rossi, (2014), Sovereign Default, Domestic Banks, and Financial Institutions, Journal of Finance, 69(2), 819-866.

[36] Giannone, Domenico, Michele Lenza, and Lucrezia Reichlin (2011), Market Freedom and the Global Recession, IMF Economic Review, 59(1), 111-135.

[37] Gorton, Gary (2010), Slapped in the Face by the Invisible Hand: Banking and the Panic of 2007, Oxford University Press.

[38] Gorton, Gary and Andrew Metrick (2012), Securitized Banking and the Run on Repo, Journal of Financial Economics, 104(3), 425-451.

[39] Gourinchas, Pierre-Olivier, Helene Rey, and Kai Truempler (2011), The Financial Crisis and the Geography of Wealth Transfers, Journal of International Economics, 88(2), 266-283.

[40] Hart, Oliver (1995), Firms, Contracts, and Financial Structure, Oxford University Press.

[41] Hellmann, Thomas F., Kevin C. Murdock, and Joseph E. Stiglitz (2000), Liberalization, Moral Hazard in Banking, and Prudential Regulation: Are Capital Requirements Enough?, American Economic Review, 90(1), 147-165.

[42] Holmstrom, Bengt and Jean Tirole (1997), Financial Intermediation, Loanable Funds, and the Real Sector, Quarterly Journal of Economics, 112(3), 663-691.

[43] Holmstrom, Bengt and Jean Tirole (1998), Public and Private Supply of Liquidity, Journal of Political Economy, 106(1), 1-40. 
[44] Huang, Rocco and Lev Ratnovski (2009), Why Are Canadian Banks More Resilient?, IMF Working Paper 09/152.

[45] Hufner, Felix (2010), The German Banking System: Lessons From the Financial Crisis, OECD Economics Department Working Papers, No. 788.

[46] IMF Global Financial Stability Report (2009), Responding to the Financial Crisis and Measuring Systemic Risks, April, Chapter 3, Detecting Systemic Risk.

[47] Jensen, Michael C. and William H. Meckling (1976), Theory of the Firm: Managerial Behavior, Agency Costs and Ownership Structure, Journal of Financial Economics, 3(4), 305-360.

[48] Jiménez, Gabriel, Steven Ongena, José-Luis Peydró, and Jesús Saurina (2014), Hazardous Times for Monetary Policy: What Do Twenty-Three Million Bank Loans Say About the Effects of Monetary Policy on Credit Risk-Taking?, Econometrica, 82(2), 463-505.

[49] Jokipii, Terhi and Alistair Milne (2008), The Cyclical Behaviour of European Bank Capital Buffers, Journal of Banking and Finance, 32, 1440-1451.

[50] Keeley, Michael C. (1990), Deposit Insurance, Risk, and Market Power in Banking, American Economic Review, 80(5), 1183-1200.

[51] La Porta, Rafael, Florencio Lopez-de-Silanes, and Guillermo Zamarripa (2003), Related Lending, Quarterly Journal of Economics, 118(1), 231-268.

[52] Laeven, Luc (2001), Insider Lending and Bank Ownership: The Case of Russia, Journal of Comparative Economics, 29, 207-229.

[53] Laeven, Luc (2002), Pricing of Deposit Insurance, World Bank Policy Research Working Paper 2871.

[54] Lindquist, Kjersti-Gro (2004), Bank's Buffer Capital: How Important Is Risk, Journal of International Money and Finance, 23, 493-513. 
[55] Martin, Antoine and Bruno M. Parigi (2013), Bank Capital Regulation and Structured Finance, Journal of Money, Credit and Banking, 45(1) 87-119.

[56] Matutes, Carmen and Xavier Vives (2000), Imperfect Competition, Risk Taking, and Regulation in Banking, European Economic Review, 44, 1-34.

[57] Mendoza, Enrique G., Vincenzo Quadrini, and Jose-Victor Rios-Rull (2009), Financial Integration, Financial Development, and Global Imbalances, Journal of Political Economy, 117(3), $371-416$.

[58] Morrison, Alan D. and William J. Wilhelm Jr. (2007), Investment Banking, Oxford University Press.

[59] Myers, Stewart C. and Raghuram G. Rajan (1998), The Paradox of Liquidity, Quarterly Journal of Economics, 113(3), 733-771.

[60] NY Fed [Federal Reserve Bank of New York] (2014), Quarterly Trends for Consolided U.S. Banking Organizations (First Quarter).

[61] Perotti, Enrico, Lev Ratnovski, and Razvan Vlahu (2011), Capital Regulation and Tail Risk, International Journal of Central Banking, 7(4), 123-163.

[62] Petersen, Mitchell A. and Raghuram G. Rajan (1995), The Effect of Credit Market Competition on Lending Relationships, Quarterly Journal of Economics, 110(2), 407-443.

[63] Repullo, Rafael (2004), Capital Requirements, Market Power, and Risk-Taking in Banking, Journal of Financial Intermediation, 13, 156-182.

[64] Shin, Hyun Song (2009), Reflections on Northern Rock: The Bank Run that Heralded the Global Financial Crisis, Journal of Economic Perspectives, 23(1), 101-119.

[65] Stein, Jeremy C. (2002), Information Production and Capital Allocation: Decentralized versus Hierarchical Firms, Journal of Finance, 57(5), 1891-1921.

[66] UBS, 2007, Annual Report. 


\section{A Proofs}

\section{A.1 Proof of Lemma 1}

First, the banker chooses safe market-based investment if $\theta \leq \theta^{*}\left(\theta^{*}\right.$ from (12)), since then $\Pi_{\text {Risky }} \leq$ $\Pi_{\text {Safe }}$. In this case, the scale of safe investment is given by $\Pi_{\text {Safe }}=b(1+X)($ from (1) and (6)), which gives: $X_{\max }^{S a f e}=(R-1-b) /(b-\varepsilon)$. Second, if $\theta>\theta^{*}$, the bank has incentives and ability to undertake the risky investment when $X_{\min }<X_{\max }$. Substituting from (11) and (14) and rearranging terms gives:

$$
b<b^{*}=\frac{(p(\alpha-\varepsilon)-(1-p)(1-\theta))(R-1)}{(1-p)(R-1)+p \alpha-\varepsilon-(1-p)(1-\theta)}
$$

The bank's profit from risky investment is increasing in $X: \partial \Pi_{R i s k y}(X) / \partial X=p \alpha-(1-p)(1-$ $\theta)>0$, where $\theta>\theta^{*}$. The bank chooses the maximum scale $X=X_{\max }$ whenever $X_{\min }<X_{\max }$.

Next, we show that the threshold $b^{*}$ is feasible: from (5) it must be that $b^{*}>p \alpha$. Substituting $b^{*}$ from (15) and rearranging terms, this holds if:

$$
(p(p \alpha-\varepsilon)-(1-p)(1-\theta))(R-1)>p \alpha(p \alpha-\varepsilon-(1-p)(1-\theta)) .
$$

This is satisfied if simultaneously:

$$
\left\{\begin{array}{l}
R>1+\frac{p \alpha(p \alpha-\varepsilon-(1-p)(1-\theta))}{p(p \alpha-\varepsilon)-(1-p)(1-\theta)} \\
\theta>1-\frac{p(p \alpha-\varepsilon)}{1-p}
\end{array}\right.
$$

where the condition for $\theta$ ensures that the right hand side of (34) is positive. 


\section{A.2 Proof of Proposition 1}

By differentiation, from (15):

$$
\frac{\partial b^{*}}{\partial R}=\frac{(p(\alpha-\varepsilon)-(1-p)(1-\theta))(p \alpha-\varepsilon-(1-p)(1-\theta))}{((1-p)(R-1)+p \alpha-\varepsilon-(1-p)(1-\theta))^{2}} .
$$

The numerator is positive for $\theta>\theta^{*}$, with $\theta^{*}$ from (12). Hence $\partial b / \partial R>0$. Next, from (5) and (14):

$$
\frac{\partial X_{\max }}{\partial R}=\frac{p}{b-p \alpha+(1-p)(1-\theta)}>0
$$

\section{A.3 Proof of Proposition 2}

By differentiation, from (15):

$$
\frac{\partial b^{*}}{\partial \theta}=\frac{(1-p)^{2}(R-1)(R-1-\varepsilon)}{((1-p)(R-1)+p \alpha-\varepsilon-(1-p)(1-\theta))^{2}}
$$

The numerator is positive from (4) and (5). Hence $\partial b^{*} / \partial \theta>0$. Also, from (5) and (14):

$$
\frac{\partial X_{\max }}{\partial \theta}=(1-p) \frac{p(R-1)-b}{(b-p \alpha+(1-p)(1-\theta))^{2}}>0
$$

Further:

$$
\frac{\partial^{2} b^{*}}{\partial R \partial \theta}=\frac{(1-p)^{2}((R-1) \varepsilon(1-p)+(2(R-1)-\varepsilon)(p \alpha-\varepsilon-(1-\theta)(1-p)))}{((1-p)(R-1)+p \alpha-\varepsilon-(1-p)(1-\theta))^{3}} .
$$

The numerator and denominator are both positive because $p \alpha-\varepsilon-(1-p)(1-\theta)>0$ for $\theta>\theta^{*}$. Finally:

$$
\frac{\partial^{2} X_{\max }}{\partial R \partial \theta}=\frac{p(1-p)}{(b-p \alpha+(1-p)(1-\theta))^{2}}>0 .
$$




\section{A.4 Proof of Proposition 3}

From the basic model, the banker undertakes risky market-based investment if $b<b^{*}$, with $b^{*}$ from (15). We show that when the risky-market based investment is available, the bank's effort in the core project is higher than when the bank is restricted to the safe market-based investment only : $e_{\text {Risky }}^{*}>e_{\text {Safe }}^{*}$, which is equivalent with :

$$
\frac{b}{c} \cdot \frac{p(R-1-\alpha)+(1-p)(1-\theta)}{b-p \alpha+(1-p)(1-\theta)}>\frac{b}{c} \cdot \frac{R-1-\varepsilon}{b-\varepsilon}
$$

yielding:

$$
p(R-1-\alpha)(b-\varepsilon)-(1-p)(1-\theta)(R-1-b)-(R-1-\varepsilon)(b-p \alpha)>0 .
$$

Rearranging terms with respect to $b$, we get:

$$
b<\frac{p(\alpha-\varepsilon)-(1-p)(1-\theta)(R-1)}{(1-p)(R-1)+p \alpha-\varepsilon-(1-p)(1-\theta)} .
$$

The expression on the right-hand side is equal to $b^{*}$, implying that for $b<b^{*}, e_{\text {Risky }}^{*}>e_{\text {Safe }}^{*}$.

\section{A.5 Proof of Proposition 4}

When the cost of funding is affected by the policy rate $i, X_{\min }$ (similar with (11)) changes to:

$$
X>X_{\min }^{i}=\frac{(1-p)(R-1-i)}{p \alpha-\varepsilon-(1-p)(1-\theta)}
$$

and $X_{\max }$ (similar with (14)) changes to:

$$
X \leq X_{\max }^{i}=\frac{p(R-1-i)-b}{b-p \alpha+(1-p)(1-\theta)+i} .
$$


The bank undertakes risky investment if $X_{\min }^{i}<X_{\max }^{i}$, or when $b<b_{i}^{*}$, with $b_{i}^{*}$ from (28). Note that $b_{i}^{*}>0$ if $\theta>1+i-\frac{p(\alpha-\varepsilon)}{1-p}$ and $\theta^{*}$ from (12) larger than $1+i-\frac{p(\alpha-\varepsilon)}{1-p}$ for $i<\varepsilon$ (which typically is true in reality, since $\varepsilon$ is the return on treasury securities). Thus, for any $\theta>\theta^{*}$, we obtain $b_{i}^{*}>0$.

Next, we show that $\frac{\partial b_{i}^{*}}{\partial i}<0$. By differentiation, from(28):

$$
\begin{aligned}
\frac{\partial b_{i}^{*}}{\partial i}= & -\frac{[p(\alpha-\varepsilon)-(1-p)(1-\theta+i)] \cdot[p \alpha-\varepsilon-(1-p)(1-\theta)]}{[(1-p)(R-1-i)+p \alpha-\varepsilon-(1-p)(1-\theta)]^{2}}- \\
& -\frac{(1-p)(R-1-i) \cdot[(1-p)(R-1-i)+p \alpha-\varepsilon-(1-p)(1-\theta)]}{[(1-p)(R-1-i)+p \alpha-\varepsilon-(1-p)(1-\theta)]^{2}} .
\end{aligned}
$$

For any $b_{i}^{*}>0$, both items of the expression above are negative, implying that $\frac{\partial b_{i}^{*}}{\partial i}<0$. Similarly, by differentiation, from (29) and (30):

$$
\begin{aligned}
\frac{\partial e_{\text {Safe }, i}^{*}}{\partial i} & =-\frac{b}{c} \cdot \frac{R-1-\varepsilon}{(b-\varepsilon+i)^{2}}<0, \text { and } \\
\frac{\partial e_{\text {Risky }, i}^{*}}{\partial i} & =-\frac{b}{c} \cdot \frac{p(b-p \alpha+i+(1-p)(1-\theta))+p(R-1+i)-b}{(b-p \alpha+i+(1-p)(1-\theta))^{2}}<0 .
\end{aligned}
$$


Figure 1. The timeline.

Date 0

- A bank attracts 1 unit of funds at the interest rate $r_{0}$ to invest in the core project.

\section{Date 1}

- A bank attracts X units of funds at the interest rate $r_{1}$ to undertake a market-based investment

- A bank can convert its assets into private benefits $b(1+X)$.
Date 2

- Projects returns are realized and distributed. 
Figure 2. The impact of the bank's core business profitability and new debt seniority on bank risk-taking.
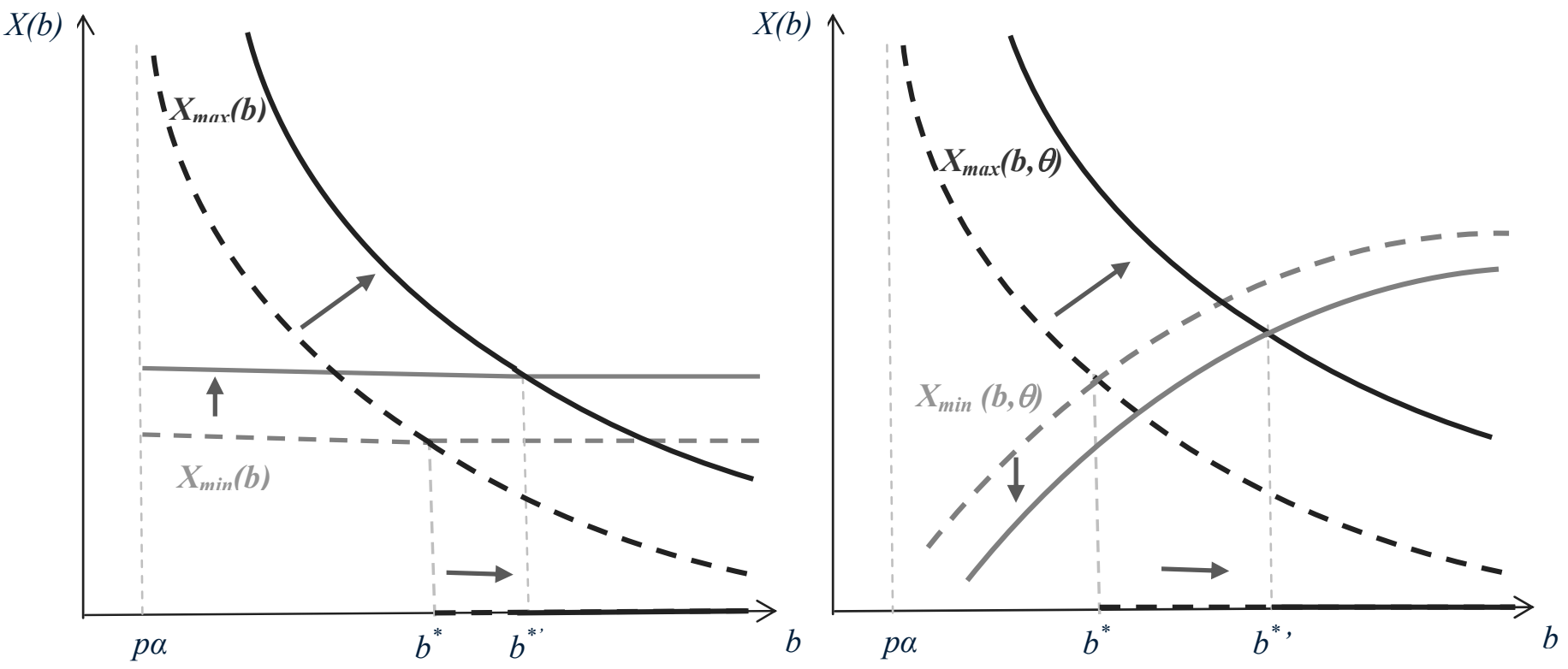

Panel A

Panel B

Panel A shows the impact of an increase in the bank's core business profitability, $R$, on the model equilibrium. Higher $R$ increases the minimal scale at which the bank finds it profitable to make the risky market-based investment $X_{\min }$, as well as the maximum feasible scale of the risky investment $X_{\max }$. On net, the effect on $X_{\max }$ dominates, and higher $R$ leads to a higher intersect $b^{*}$, indicating a wider range of parameter values for which a bank undertakes the risky investment.

Panel B shows the impact of an increase in feasible date 1 debt seniority, $\theta$, on the model equilibrium Higher $\theta$ reduces the minimal scale at which the banks finds it profitable to make the risky marketbased investment $X_{\min }$, as well as increases the maximum feasible scale of the risky investment $X_{\max }$. As a result, higher $\theta$ leads to a higher intersect $b^{*}$, indicating a wider range of parameter values for which a bank undertakes the risky investment. 
Figure 3. Solution with endogenous $r_{0}$.

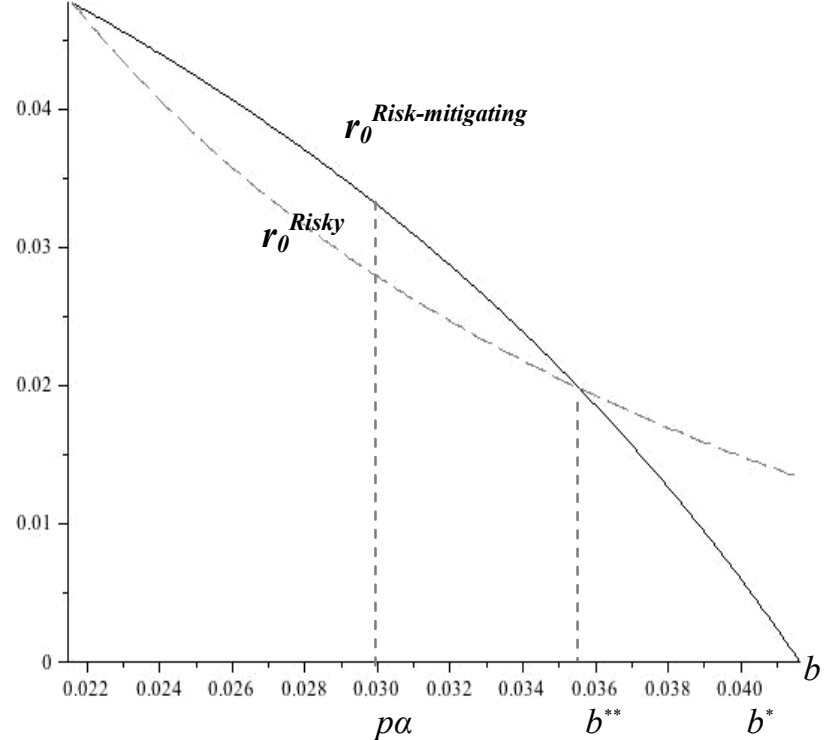

Panel A

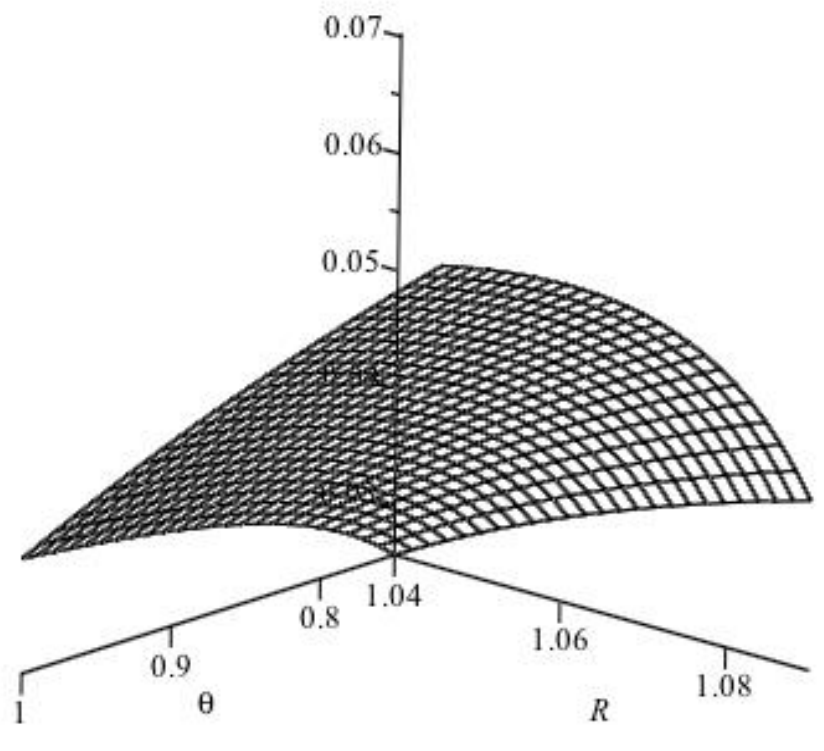

Panel B

Panel A shows the evolution of the interest rate required by date 0 creditors depending on $b$, for the following set of parameter values: $R=1.07 ; \varepsilon=0.02 ; \alpha=0.03 ; p=0.97 ; \theta=0.75$. Laxer leverage constraint (as indicated by lower $b$ ) increases both the ineterst rate the prices bank risk-taking $r_{0}{ }^{\text {Risky }}$ and the interest rate that prevents bank risk-taking $r_{0}{ }^{\text {Risk-Mitigating }}$. For $b^{* *}<b \leq b^{*}, r_{0}{ }^{\text {Risk-Mitigating }}<r_{0}{ }^{\text {Risky }}$; accordingly date 0 creditors set $r_{0}=r_{0}^{\text {Risk-Mitigating }}$ and the bank chooses the safe market-based investment. For $b<b^{* *}, r_{0}{ }^{\text {Risky }}<r_{0}{ }^{\text {Risk-Mitigatin }}$; date 0 creditors set $r_{0}=r_{0}{ }^{\text {Risky }}$ and the bank chooses the risky market-based investment. Under the model assumptions, the area of interest is $b>p \alpha$.

Panel B shows the evolution of threshold $b^{* *}$ depending on core profitability, $R$, and the feasible date 1 debt seniority, $\theta$, for the following set of parameter values: $\varepsilon=0.02 ; \alpha=0.03 ; p=0.97$. Higher $R$, as well as higher $\theta$, lead to a higher $b^{* *}$, indicating a wider range of parameter values for which a bank undertakes the risky market-based investment. 
Figure 4. Effort in the core project: The timeline.

\section{Date 0}

- A bank attracts 1 unit of funds at the interest rate $r_{0}$ to invest in the core project

- A bank can exert effort to increase the probability of success of the core project.

\section{Date 1}

- A bank attracts X units of funds at the interest rate $r_{1}$ to undertake a market-based investment

- A bank can convert its assets into private benefits $b(1+X)$.

\section{Date 2}

- Projects returns are realized and distributed. 